InOedia $\quad \begin{aligned} & \text { InMedia } \\ & \text { The French Journal of Media Studies }\end{aligned}$

$2 \mid 2012$

Performing/Representing Male Bonds

\title{
Kathleen Franz and Susan Smulyan (eds), Major Problems in American Popular Culture
}

Boston: Wadsworth Cengage Learning, 2011, 496 p.

Elsa Grassy

\section{OpenEdition}

\section{Journals}

Electronic version

URL: http://journals.openedition.org/inmedia/474

DOI: $10.4000 /$ inmedia.474

ISSN: 2259-4728

Publisher

Center for Research on the English-Speaking World (CREW)

Electronic reference

Elsa Grassy, « Kathleen Franz and Susan Smulyan (eds), Major Problems in American Popular Culture », InMedia [Online], 2 | 2012, Online since 13 December 2012, connection on 22 September 2020. URL http://journals.openedition.org/inmedia/474 ; DOI : https://doi.org/10.4000/inmedia.474

This text was automatically generated on 22 September 2020 .

(c) InMedia 


\title{
Kathleen Franz and Susan Smulyan (eds), Major Problems in American Popular Culture
}

Boston: Wadsworth Cengage Learning, 2011, 496 p.

\author{
Elsa Grassy
}

\section{REFERENCES}

Kathleen Franz and Susan Smulyan (eds), Major Problems in American Popular Culture, Boston: Wadsworth Cengage Learning, 2011, 496 p.

1 So far, most popular culture readers published have been collections of essays (like The Soul of Popular Culture, edited by Mari Lynn Kittelson as early as 1987), or collections of theoretical texts presenting a more or less felicitous or enlightening medley of French theory and postmodernism. In the second category, John Storey's Cultural Theory and Popular Culture: A Reader (Pearson/Prentice Hall, 2006) - part of a diptych with Cultural Theory and Popular Culture: An Introduction (Pearson Education, 2006) - runs the gamut of conceptual tools available to the popular culture scholar through founding texts and other secondary sources, from Marxism to Postmodernism via Feminism and Structuralism. Then there are more thematic, but just as theoretical books, like Cultural Studies and the Study of Popular Cultures: Theories and Methods (Edinburgh University Press, 1996), another Storey opus whose chapters focus on TV, fiction, film, the press, music, consumption, and globalization. Those books are obviously destined to graduate students and researchers.

2 By contrast, Kathleen Franz and Susan Smulyan's Major Problems in American Popular Culture is both a historians' book, and one that - in spite of its limitations - will prove fitting for use in the classroom, especially when teaching undergraduates. The authors focus on fourteen topics in American popular culture, presented in chronological order. Following the usual format for the collection, each chapter starts with a general 
introduction, followed by primary sources covering several 'popular culture' specificities of the period, and then by essays about the same topics. A useful bibliography closes each chapter. The book is complemented by a website giving access to various resources, including audio and video recordings, sheet music collections, as well as links to museums and exhibits websites.

Despite the promise of the book's title, it must be stressed that the reader will not find here a list of issues pertaining to the study of American popular culture. In the preface to the book, the authors make it clear that "the documents and essays in this volume address four major problems that historians encounter in studying an interpreting popular culture: defining our object of study, the role of audiences, the relationship between popular culture and society, and how to think about the globalization of cultures" (xv). Identity (gender, class, and race), technologies, commercialization and the role of the nation state are identified as secondary 'problems.' Hence, although the opening chapter strives to define popular culture as a research object and makes the case for studying it (with essays by George Lipsitz, Stuart Hall, and John Clarke), the collection does not read as an investigation of various issues relating to American popular culture per se. Rather, it is a history of American popular culture taken piece by piece, with each chapter listing issues for the period under consideration.

The 'major problem' of this book for American Studies scholars might be that the "major problems" tackled here are not made understandable by the historical periods studied; rather, they themselves provide illustrations (taken from popular culture) for the periods studied. It is quite revealing that the first chapter, "Why Study Popular Culture", should focus on the birth of popular culture studies "as a subfield of history." Major Problems in American Popular 'History' would be a more accurate title. While the authors quote George Lipsitz, saying, "popular culture is not the side show of history, but rather the main event" (2) - popular culture is precisely treated here as an 'event,' not as a stream that connects several generations and periods in American history. Fragmenting the popular narrative into historical tableaux obscures its nature as a contested terrain where visions collide, merge, disappear, then resurface, ad lib.

Given the width of the material the authors tried to cover, this is not a perfect book even for historians. Some widely studied issues are all but absent from the work (LGBT, subcultures, space and place, and tourism, to name but a few), while others are leitmotivs. Race, for example, is the central theme chosen for the chapter on the second half of the $19^{\text {th }}$ century and minstrel shows, then makes cameo appearances in chapter 8 ("Cars as Popular Culture: Democracy, Racial Difference, and New Technology, 1920-1939"), chapter 10 ("Defining Popular Music: The Concept of Authenticity and the Role of Culture Brokers, 1935-1950"), and chapter 13 ("Popular Culture and Globalization: Beyond Imperialism"). And while there are two chapters devoted to the 1950s (11: "Television Becomes Part of the Family, 1955-1965" and 12: "Youth and Popular Culture during the Cold War, 1952-1960"), the Counterculture is conspicuously absent from the volume, except for a quick mention page 381.

Given the scope of the project, one understands that the authors have proposed an itinerary (the panoramic kind) of American popular culture, which, all things said, does not really fulfill the promises of the title. Each chapter does not truly address a 'problem' of popular culture, but rather a period in the history of popular culture, with its core and secondary issues. This is clearly the authors' aim, as stated in the first line 
of the preface: "Popular culture presents a critical group of players, texts, and activities for examining the history of everyday life in the United States" (emphasis mine).

7 The interest of the book rests mostly on its wealth of primary sources, a valuable asset for teachers of American popular culture. In each chapter, essays are paired with relevant primary sources, including advertising, photographs, speeches, and excerpts from plays or novels. As such, this volume can be compared to Jim Cullen's Popular Culture in American History (Wiley-Blackwell, 2001), whose ten essays similarly combine primary and secondary sources; although in reverse order, which guarantees a better understanding of primary documents. While some may prefer a less directed gaze, one regrets the lack of suggested questions on the texts. The separation of primary and secondary sources (the required format for the collection), and the lack of a general introduction establishing links between both kinds make it harder to understand at first sight why a picture of a Native American family in a car was chosen for the chapter on the automobile. It is only later, in the introduction to the secondary sources for the chapter, that the global pattern is revealed, the second part of the chapter including an essay on Native Americans and cars. The same goes for the 'Fireside Chat' chosen to illustrate the advent of the radio in America: the text seems out of place, and even when put in perspective with the corresponding essay, it tells us more about FDR than on the significance of the radio. While the chapters in the Cullen book are also presented in chronological order, and may appear as case studies of a particular moment of popular culture, connections are made across periods. This is something that Smulyan and Franz's book is missing, especially in the absence of a thematic index.

Franz and Smulyan's ability to gather fascinating sources on aspects of American popular culture commands respect, and the introduction, which lists websites and academic associations devoted to the study of popular culture, will be useful to aspiring popular culture scholars. But this book will disappoint popular culture specialists by its lack of focus on 'problems' for the sake of historical perusal. While Major Problems in American Popular Culture won't help graduate students of American popular culture delve into matters of race, class, gender, age, mediation, and other 'major problems' thoroughly, it will provide professors teaching panoramic undergraduate classes on American popular culture a suitable itinerary.

\section{AUTHORS}

ELSA GRASSY

Université de Strasbourg 